\title{
In Search of Quality Human Resources in Education: Professional Competency, Compensation, Working Climate, and Motivation toward Vocational Teachers' Performance
}

MUAZZA*

\begin{abstract}
This study aimed to find out the effect of professional competency, compensation, working climate, and motivation on the performance of vocational teachers in Muaro Jambi Regency. The data were collected through an empirically validated questionnaire from 212 respondents. The variables consisted of professional teacher competency

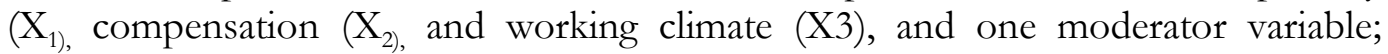
motivation $(\mathrm{Y})$, and one bound variable; teacher performance $(\mathrm{Z})$. Descriptive and inferential analysis technique was used to analyze the data through SPSS and Smart PLS 3.2.7 applications. The results of descriptive analysis illustrated that teacher performance, teacher professional competency, working climate and working motivation in the very high category. At the same time, compensation fell into the good category. The statistical analysis results revealed that teacher professional competency, compensation, and working climate affected teacher working motivation, while professional teacher competency, working climate, and motivation involved teacher performance. Compensation was predicted not to affect teacher performance where P-Value 0.810 was greater than 0.05. Teacher professional competency, compensation, and working climate affected teacher performance through motivation as moderator variables to teacher performance. Professional teacher competency, compensation, and working climate were predicted to have a simultaneous effect on teacher working motivation. Professional teacher competency, compensation, working climate, and motivation were predicted to have a simultaneous effect on teacher performance. It is recommended that vocational school teachers in Muaro Jambi regency improve their performance for better student learning achievement.
\end{abstract}

\section{Keywords}

Compensation, motivation, vocational school, teacher professional competency, working climate

* Associate Professor, Faculty of Teacher Training and Education, Universitas Jambi, Indonesia; muazza@unja.ac.id 


\section{IRJE | Indonesian Research Journal in Education | | Vol. 5 | No. 1|June | Year 2021|}

\section{Introduction}

The National Exam in 2019 attended by 1,361 vocational school students in Muaro Jambi regency was declared to pass $100 \%$ with an average Score of Bahasa Indonesia 56.55 (moderate category), English 35.43 (low category), Mathematics 30.76 (low category) and Vocational Theory 40.80 (low category). These showed the low competitiveness of vocational school graduates who planned to continue their education to college. There are no vocational school graduates in Muaro Jambi regency who obtained LSP-P1/professional certificates in terms of skills. An LSP-P1 certificate is a form of recognition from professional certification bodies for one's competency. This shows the lack of competitiveness of vocational school graduates in competing for jobs available in the industrial world as well as opening independent businesses.

Several facts are inseparable from the duties and roles of teachers who are expected to contribute significantly in efforts to improve student achievement. Teachers should improve the quality of their learning through sustainable professional development activities to improve learning management skills. The increasing professional competency of teachers is expected to have a positive impact on their performance. Some of the teachers' weaknesses in vocational schools in Muaro Jambi regency included skills to develop a learning program plan, skills to stretch the learning process, and skills to assess the learning process. According to Madjid (2016), teacher performance is not optimal among others due to displeased and lazy work, leaving teaching hours before the end, poor working performance, low quality in teaching, undisciplined, and others. Considering the position of teachers as the main element in the school, a solution should be sought. In addition to the professional competency of teachers, according to Madjid (2016), teacher performance is influenced by compensation, working climate, and motivation. The results of teacher supervision in vocational schools in Muaro Jambi regency obtained the following information; low wages of contracted teachers, unconducive working climate, such as the idea of authoritarian principals, and lack of opportunities to develop, such as training activities dominated by certain teachers. If these continue, they will affect the progress of the school.

The fact that the working climate occurred in Muaro Jambi regency based on the author's observations relates to the relationship between superiors and subordinates, which is not harmonious. There are duplicate positions, unfair rewards as a cause of poor relations between teachers, and depressed feeling by leadership that is not focused on students.

The preliminary data revealed that compensation received by teachers in the vocational school in Muaro Jambi regency based on the author's observations related to low wages, the payment system of contract teachers is late, lack of welfare resources in addition to teaching salaries, such as health benefits, uniforms, and transport assistance, and long distance from the provincial capital of civil servant teachers' lives makes difficult when they manage promotions and periodic salaries. Furthermore, Madjid (2016) stated that teachers who work well would perform well. Good performance can encourage moral teachers to act with more achievement. This is supported by the findings of Wuandari and Purwanto (2018), Kurniasih (2018), Ningsih (2017), and Zulkefi et al. (2017), which stated that teacher 


\section{IRJE | Indonesian Research Journal in Education | | Vol. 5 | No. 1|June | Year 2021|}

professional Competency has a positive and significant effect on teacher performance. However, Sadili (2006) argues that the school's success is affected by several factors, including compensation. The leadership's attention to compensation arrangements in schools rationally and independently is necessary to attract applicants and retain existing teachers to motivate themselves to perform well. Similarly, if teacher compensation does not refer to education, competency, position, and tenure, it can lead to decreased motivation and working performance. Widayati (2019), Marsita and Imaniyati (2018), and Mutakin (2017) showed a positive and significant influence between compensation for teacher performance variables. However, Purwanto et al. (2019) research stated that the compensation received by teachers did not affect their performance. There are differences in the results of research (research gap) from researchers. Hence more studies on teacher compensation need to be carried out.

Another variable highlighted is about working climate. Suharsaputra (2010) argues that working climate is an effective environment expected to affect performance through the working behavior of members in carrying out tasks in a conducive and efficient communication atmosphere. Schools with an excellent working climate will have a good impact on performance. This is supported by the research of Purwanto et al. (2019), Vahim et al. (2019), and Maesaroh (2018), which stated that working climate has a positive and significant effect on teacher performance. In contrast to Carudin's research (2011), he stated that working climate does not affect teacher performance. The last variable outlined in this study is motivation. Mangkunegara (2005) concluded that motivation of achievement has a positive relationship with performance achievement. This means that the motivation to perform well by teachers will lead to high performance. On the contrary, underperforming teachers are due to poor working motivation. This statement is supported by Madi and Kalimin (2019), Sari (2018), Maesaroh (2018), Yulia (2017), and Ardiana (2017) which stated that motivation has a positive and significant effect on teacher performance. Based on the problems related to teacher performance and lack of research on teacher performance in vocational schools in Muaro Jambi regency, it is interested in conducting particular research discussing the effect of teacher professional Competency, compensation, working climate, and motivation on teacher performance in vocational schools in Muaro Jambi regency.

\section{Literature Review}

\section{Teacher performance}

Some experts interpret performance as the result of work or working performance. According to Wibowo (2010) has a broader meaning, not only as a result of work but including the procedure of work is organized. According to Rowley and Jackson (2012), performance relates to the term evaluation (performance), assessment or review. Therefore, performance can be measured and improved at various human resource management activities such as organization, team, or individual. Thus, performance refers to the degree of completion of employee duties and in Indonesia, based on Permeneg PAN-RB No. 16 of 2009, teacher performance covers planning, implementation, and learning assessment. According to Anoraga (2006), some factors that affect performance include salary system, job attractiveness, 


\section{IRJE | Indonesian Research Journal in Education | | Vol. 5 | No. 1|June | Year 2021|}

job security and comfort, management system, physical and social environment, career path, and leadership. By understanding the factors that can affect the performance of teachers or employees, various problems can be found solutions to be obstacles to improve its performance. Based on expert opinion, teacher performance can be concluded as a comparison between the work obtained by teachers and the work objectives agreed together with the supervisor based on the main tasks and functions inherent to a person in carrying out daily tasks according to the authority responsibility. More specifically, the performance measures used in this study is the result approach of teachers/teams, assuming subjectivity can be eliminated. According to Uno (2013), teacher performance gauge can be seen from speed or accuracy of work, quality of work, initiative in work, working ability, and proficiency in working communication.

\section{Professional competency, compensation, working climate, and working motivation}

Wibowo (2010) notes competency is a person's ability to do work based on knowledge, skills and working attitudes that become the demands of his work. Madjid (2016) emphasizes that competency has three meanings; (1) Competency (n) is being competent, ability (to do the work), (2) competent (adj) refers to persons having ability, power, authority, skill, knowledge, etc. (to do what is needed), and (3) competency is a rational performance which statisfactority meets the objectives for the desired conditions. Besides, Yamin and Maisah (2010) argue that teacher Competency is a certain measure determined and required in the form of an assignment to behave like a person who occupies the functional position of a teacher following the field of duty, qualifications, and educational level.

According to Hasibuan (2017), compensation represents the entirety of income in the form of money and goods directly or indirectly received by employees in return for services provided by the company. Similarly, Wibowo (2010) said that parties should provide compensation using personnel or services (individuals or business organizations). Sastrohadiwiryo (2005) defines compensation as the reward of services provided by the company to employees because it has provided services for the company's advancement to achieve the goals set. From the exposure of the experts, compensation can be concluded in return for services provided by the company to workers for the contribution of services from their work, to maintain and improve their motivation and performance. It can take the form of direct compensation in the form of salaries, benefits, incentives, and indirect compensation in financial benefits such as housing allowances, health insurance, and holiday allowances.

According to Robbins (2007), working climate is a term often used to string together behavioral variables based on values, beliefs, and basic norms that serve as a guide to the management system of the organization. Hardiana (2006) argues that working climate is a typical personality of the organization differentiating with other organizations to guide the perception of members in looking at the organization. Additionally, Daryanto (2015) strengthens that working climate is a relationship between personnel, social and cultural factors to affect individuals and groups in the school environment. In brief, the measurement of the working climate in this study includes dimensions of; (1) the relationship of superiors with subordinates; (2) relationships with school members; (3) personal responsibility; (4) fair 


\section{IRJE | Indonesian Research Journal in Education | | Vol. 5 | No. 1|June | Year 2021|}

reward; (5) control, structure, and logical bureaucratic system; and (6) the involvement and participation of teachers/ employees.

Motivation comes from the word movere (Latin), which means the same as to move (English) which means to encourage or move (Kadarisman, 2012). Wibowo (2010) argues that motivation is one's desire to act. The motivation that arises can come from a lot of strength. Therefore, the leadership should affect the work to adjust its motivation to the interests of organization. Shortly, motivation is a process that allows producing intensity, direction, and continuous effort (persistence) from the individual to achieve goals. Hasibuan (2007) adds the objectives of motivating employees included stimulating the passion and spirit of work, improving morale and job satisfaction, increasing productivity, maintaining loyalty, improving discipline, building a good atmosphere and working relationship, improving the level of well-being, maintaining and enhancing creativity and participation, and increasing the employee's sense of responsibility for their duties.

\section{Research hypotheses}

The following hypotheses would be the focused of the study:

H1: There is a partial effect of teacher's professional competency on motivation of vocational school teachers.

H2: There is a partial effect of compensation on the motivation of vocational school teachers.

H3: There is a partial effect of working climate on motivation of vocational school teachers.

H4: There is a significant effect of teacher professional Competency on the performance of vocational school teachers.

H5: There is a significant effect of compensation on the performance of vocational school teachers.

H6: There is a significant effect of working climate on the performance of vocational school teachers.

H7: There is a significant effect of motivation on the performance of vocational school teachers.

H8: There is a significant effect of professional competency on teacher performance through the motivation of vocational school teachers.

H9: There is a significant effect of compensation on teacher performance through motivation of vocational school teachers.

H10: There is a significant effect of working climate on teacher performance through motivation of vocational school teachers.

\section{Methodology}

\section{Research design, site, and participants}

To answer research problems and questions, this study used the quantitative research method to develop variables studied by using mathematical models, theories and testing hypotheses to produce statistical data. Creswell (2011) states that one of the main characteristics of quantitative research is collecting numerical data from many people using instruments with predetermined questions, associating variables using statistical analysis and comparing research results with previous predictions. Moreover, a quantitative research method was used to test the proposed hypothesis. Creswell (2011) that in this scenario, the 


\section{IRJE | Indonesian Research Journal in Education | | Vol. 5 | No. 1|June | Year 2021|}

researcher tests a theory by specifying hypotheses and the collection of data to support or refute the hypotheses

Furthermore, quantitative research consists of two types of approaches/ designs, experimental and non-experimental such as survey (Creswell, 2012). Following the problem studied, this study used a non-experimental research design. The survey research process is a social phenomenon in education that attracts researchers' attention. The use of survey methods in this study was more suitable for finding out the perception picture of the variables studied by asking the same question to the sample of the selected population. In addition, a survey was chosen to ensure participants' perception of the variables.

This study was conducted in vocational schools Muaro Jambi regency. The population of this study was all teachers in vocational schools Muaro Jambi regency with a number of 450 teachers subjects, both civil servants and contract teachers in public-private vocational schools. Possible errors should be addressed as little as possible with a level of error 0.05 which means a confidence level of $95 \%$ of the samples count in this study was as many as 212 participants.

\section{Data collection and analysis}

The PLS-SEM technique was used to analyze data and proposed hypotheses by using Smart PLS software (Carrión, Henseler, Ringle, \& Roldán, 2016; Hair, Hult, Ringle, \& Sarstedt, 2017; Ratzmann, Gudergan, \& Bouncken, 2016). PLS-SEM as a variance-based technique has enjoyed increased popularity in various disciplines, including entrepreneurship (Hernández-Perlines, 2016). Many studies to date have explored various factors that affect an individual's intention to enter business, primarily using regression methods (Shirokova, Osiyevskyy, \& Bogatyreva, 2015; Shook \& Bratianu, 2010). In this study, a more comprehensive view to analyze the entire set of reciprocal relationships.

\section{Findings}

The reliability aimed to assess whether the latent variable measurement indicator was reliable or not. The trick was to evaluate the outer loading results of each indicator. Loading values above 0.7 indicated that the construct could explain more than $50 \%$ of its indicator variances (Heir et al., 2017). In this study, all loading values were above 0.7 and only one below 0.7 and can be displayed above 0.7. Internal Consistency Reliability measures how capable indicators can measure their latent constructs (Heir et al., 2017). The tools used to assess were composite reliability and Cronbach's alpha. Composite reliability values of $0.6-0.7$ were considered good reliability (Heir et al., 2017), and Cronbach's alpha value was expected to be above 0.7 (Ghozali \& Latan, 2015). The validity of convergence is determined based on the principle that the gauges of a construct should be highly correlated (Ghozali \& Latan, 2015). The convergent validity of a construct with reflective indicators was evaluated with Average Variance Extracted (AVE). The AVE value should be equal to 0.5 or more. Ave value of 0.5 or more means the construct can explain 50\% or more variance of the item (Heir et al., 2017). 
Table 1. Construct reliability and validity

\begin{tabular}{llllc}
\hline & Alpha & rho_A & CR & (AVE) \\
\hline Working Climate & 0,909 & 0,909 & 0,923 & 0,645 \\
Teacher Performance & 0,913 & 0,914 & 0,944 & 0,677 \\
Compensation & 0,942 & 0,943 & 0,943 & 0,755 \\
Working Motivation & 0,834 & 0,887 & 0,942 & 0,811 \\
Professional Competencies Teacher & 0,874 & 0,875 & 0,923 & 0,666 \\
\hline
\end{tabular}

The reliability test in PLS can use two methods, Cronbach'salpha and Composite reliability. According to Hair et al. (2017), The composite reliability and Cronbach alpha values were examined accompanied by the mean of variance extracted (AVE) to check the reliability of the assessment model. All Cronbach's alpha coefficients and composite reliability should be greater than 0.7 , although a value of 0.6 was still acceptable. However, the internal consistency test was not necessary if the construct validity has been fulfilled because a valid construct was a reliable construct. On the other hand, a reliable construct was not necessarily valid (Hair et al., 2017). Composite reliability varied from 0.902 to 0.932. In addition, the AVE value ranged from 666 to .811. All values in this study included Cronbach's alpha, composite reliability, and AVE was acceptable. Therefore, the data can be inferred as valid and reliable. Descriptive Validity Individual reflective measure is high if it correlates more than 0.70 with the construct to be measured. However, in the early stages of developing a measurement scale, the loading value of 0.50 to 0.60 was considered sufficient (Ghozali, 2015). Discriminant validity aims to determine whether a reflective indicator is a good measure for its construct based on the principle that each indicator should be correlated. In the SmartPLS 3.2.7 application, the discriminant validity test used the value of Fornell-Larcker Criterion and Heterotrait-Monotrait (HTMT) ratio (Henseler et al., 2015).

Table 2. Fornell-Larcker Criterion

\begin{tabular}{llllll}
\hline & $\begin{array}{l}\text { Working } \\
\text { Climate }\end{array}$ & $\begin{array}{l}\text { Teacher } \\
\text { Performance }\end{array}$ & Compensation & $\begin{array}{l}\text { Motivation } \\
\text { Work }\end{array}$ & $\begin{array}{l}\text { Teacher } \\
\text { Professional } \\
\text { Competency }\end{array}$ \\
\hline Working Climate & 0,822 & & & & \\
Teacher Performance & 0,662 & 0,747 & & & \\
Compensation & 0,629 & 0,557 & 0,817 & & \\
Working Motivation & 0,581 & 0,523 & 0,701 & 0,901 & 0,816 \\
$\begin{array}{l}\text { Teacher Professional } \\
\text { Competency }\end{array}$ & 0,345 & 0,322 & 0,189 & 0,186 & \\
\hline
\end{tabular}

In this case, the square root value of AVE in each construct was greater than the correlation value between the construct and other constructs in the model tested; then, the model can be inferred to have a good discriminant validity value (Fornell-arscher, 1988). 


\section{IRJE | Indonesian Research Journal in Education | | Vol. 5 | No. 1|June | Year 2021|}

Table 3. Heterotrait-Monotrait Ratio (HTMT)

\begin{tabular}{lllll}
\hline & $\begin{array}{l}\text { Working } \\
\text { Climate }\end{array}$ & $\begin{array}{l}\text { Teacher } \\
\text { Performance }\end{array}$ & Compensation & $\begin{array}{l}\text { Motivation } \\
\text { Work }\end{array}$ \\
\hline $\begin{array}{l}\text { Working Climate } \\
\text { Teacher Performance }\end{array}$ & 0,716 & & & \\
Compensation & 0,692 & 0,611 & & \\
Working Motivation & 0,644 & 0,580 & 0,784 & \\
Teacher Professional Competency & 0,395 & 0,353 & 0,213 & 0,212 \\
\hline
\end{tabular}

Some experts argue Fornell-Larcker Criterion is less sensitive in assessing the validity of discriminants. HTMT is an alternative method recommended for assessing the validity of discriminants. This method used a multitrait-multimethod matrix as the basis of measurement. The HTMT value should be less than 0.9 to ensure the validity of the discriminant between the two reflective constructs (Henseler et al., 2015). Based on the results of the data, all values were less than 0.9. Therefore, it can be inferred that the research instrument used was valid.

Table 4. Mean, STDEV, T-V alues, and P-V alues

\begin{tabular}{lllll}
\hline H & Path & $\beta$ & T value & $\begin{array}{l}\text { P } \\
\text { Values }\end{array}$ \\
\hline H1 & Teacher Professional Competency -> Working Motivation & 0,417 & 4,730 & 0,000 \\
H2 & Compensation -> Working Motivation & 0,291 & 2,792 & 0,005 \\
H3 & Working Climate -> Working Motivation & 0,183 & 2,401 & 0,017 \\
H4 & Teacher Professional Competency -> Teacher Performance & 0,088 & 13,879 & 0,000 \\
& Compensation -> Teacher Performance & $-0,016$ & 0,241 & 0,810 \\
H5 & Working Climate -> Teacher Performance & 0,128 & 2,451 & 0,015 \\
H7 & Working Motivation -> Teacher Performance & 0,262 & 3,785 & 0,000 \\
\hline
\end{tabular}

Hypothesis 1 , the P-Value of 0.000 or less than 0.05 , mean a significant effect of professional competency of teachers on working motivation. Hypothesis 2 , the effect of compensation on teacher working motivation was $29.1 \%$ and P-Value of 0.005 or less than 0.05 . This meant that there was a significant effect of compensation on working motivation of the teachers. Hypothesis 3, the effect of working climate on teacher working motivation by $18.3 \%$ and the value of P-Value 0.017 or smaller than 0.05 meant that there was a significant effect of working climate on motivation of teachers in vocational schools in Muaro Jambi. Hypothesis 4, the effect of professional competency of teachers on the performance of $68.8 \%$ and the value of P-Value was 0.000 or less than 0.05 . This meant that there was a significant effect of teacher professional Competency on teacher performance. Hypothesis 5, compensation has no significant effect on teacher performance in vocational schools in Muaro Jambi regency. Hypothesis 6, the effect of working climate on teacher performance by $12.8 \%$ and the value of 


\section{IRJE | Indonesian Research Journal in Education | | Vol. 5 | No. 1|June | Year 2021|}

P-Value 0.015 or smaller than 0.05 , which meant that there was a significant effect of working climate on teacher performance in vocational schools in Muaro Jambi regency. Hypothesis 7 , the effect of motivation on teacher performance by $26.2 \%$ with a value of P-Value of 0.000 or less than 0.05 meant that there was a significant effect of working motivation on teacher performance in vocational schools in Muaro Jambi regency.

Table 5. Mean, STDEV, T-V alues, and P-V alues on X-> Y-> Z

\begin{tabular}{lllll}
\hline $\mathbf{H}$ & Path & $\boldsymbol{\beta}$ & T value & P-Values \\
\hline H8 & $\begin{array}{l}\text { Teacher Professional Competency -> Working } \\
\text { Motivation -> Teacher Performance }\end{array}$ & 0,109 & 3,021 & 0,003 \\
H9 & $\begin{array}{l}\text { Compensation -> Working Motivation -> Teacher } \\
\text { Performance }\end{array}$ & 0,076 & 2,304 & 0,022 \\
H10 & $\begin{array}{l}\text { Working Climate -> Motivation } \\
\text { Work -> Teacher Performance }\end{array}$ & 0,048 & 2,118 & 0,035 \\
\hline
\end{tabular}

Hypothesis 8, the effect of professional competency of teachers through moderation or indirect with motivational moderator variables on teacher performance with a value of P-Value 0.035 or smaller than 0.05 and an original sample of 0.109 meant that there was a significant effect of teacher professional Competency on teacher performance through motivation moderation. Hypothesis 9, there was an effect of compensation through moderation or indirect motivation as a moderator variable on teacher performance with the original sample of 0.076 . It meant that the effect of compensation on teacher performance was $7.6 \%$, with a value of P-Value of 0.022 or less than 0.05 . Hypothesis 10 , the effect of working climate through moderation or indirect motivational variable on teacher performance with the original sample of 0.048 meant that the effect of working climate on teacher performance was $4.8 \%$ with a P-Value of 0.035 .

\section{Discussion}

Teacher professional competency affects teacher motivation, according to McClelland's Theory (Achievement Motive Theory), action is carried out by someone driven by the need to achieve the best in order to achieve goals (Kadarisman, 2012). This theory believes that achievement has a very important role in a person's success to achieve his goals. A teacher will mobilize or encourage all the best knowledge, behavior, and skills (Competency) to achieve the best. This means that a teacher who has competency will foster self-confidence due to the belief that other people will respect his appearance. Moreover, the higher professional competency of the teacher will increase the working motivation of the teacher. This is in line with Kasman's study (2018) on the effect of teacher Competency on student learning motivation at SMA Negeri 10 Makassar, which states that there was a significant effect between teacher Competency on student learning motivation at SMA Negeri 10 Makassar. The results of the study had a positive effect on teacher working motivation.

Compensation affects teacher working motivation, the results of this study support Vroom's theory of expectation motivation in Kadarisman (2012) which views that a person works in order to realize his hopes from his job. Thus, an employee will be more enthusiastic about 


\section{IRJE | Indonesian Research Journal in Education | | Vol. 5 | No. 1|June | Year 2021|}

working well when they believe that their achievements will get a big reward. Someone sees opportunities for rewards, such as increases in salary and position if he works actively. It becomes an incentive (stimulus) for employees to work more optimally. Rivai (2013) states several aspects that affect working motivation, such as feeling safe, getting a fair and competitive salary, a pleasant environment to work for, appreciation for achievement and fair management. In brief, it can be predicted that the higher or greater the rewards given to teachers by the school will increase their work motivation as well as the more balance between direct compensation and indirect compensation received by teachers predicted to increase their work motivation. The results of this study were in line with a study conducted by Hardiyana, Iskandar, and Nurlaila (2013) regarding the effect of organizational culture and compensation on working motivation and its implications for teacher performance. Therefore, there was a partial effect and compensation had an effect on working motivation by $19.18 \%$. This was in line with the results of Lubis' study (2018).

Working climate affects working motivation, the results of this study support McClelland's theory in Kadarisman (2012) which states that the need to be affiliated (Need for Affiliation) becomes an individual driving force to utilize the energy that stimulates individuals to complete work because of their desire such as accepted by colleagues and the environment, respected because they feel important, and going forward and not failing. In short, working climate is more conducive or better predicted to further increase teacher working motivation. Teachers as social beings who cannot be denied. There are mutually respectful and positive interactions. The opposite will happen when working climate in schools is less conducive, and it is predicted that it will have an impact on the decrease in the enthusiasm or motivation of the teacher's work.

Teacherprofessional competency affects teacherperformance, the results of this study support the theory of Madjid (2016) which states that teacher performance is related to their level of competency. A teacher who has high performance should be supported by high competency. Yamin and Maisah (2010) argue that teacher Competency is a certain predetermined measure required in the form of an assignment to behave like someone who is in a functional teacher position in accordance with the field of duty, qualification, and level of education. Therefore, to do a job requires certain competencies, the completion of the work becomes faster, easier, cheaper and of high quality. Previous study conducted by Patarai, Mustari and Azis (2018) on teaching motivation, professional Competency and education level on teacher performance found that the professional competency of teachers has a significant effect on teacher performance in a vocational school Negeri 4 Soppeng. This result was in line with a study conducted by Mutakin (2017).

Compensation affects teacher performance, compensation according to Werther and Davis (2010) relates compensation to employee performance. In this case, compensation given to employees as a form of reward refers to performance and is not based on seniority or the number of hours worked. Rivai (2013) states that if it is managed properly, compensation will help the company to achieve its goals and obtain, maintain, and look after employees properly. Conversely, the result of a feeling of dissatisfaction with less payment will reduce performance. The result of this study was in line with Riyadi's study (2011) on the effect of financial compensation, leadership style, and working motivation on employee performance. The results showed that there was no effect of financial compensation (X1) on work 


\section{IRJE | Indonesian Research Journal in Education | | Vol. 5 | No. 1|June | Year 2021|}

motivation (Z), leadership style (X2) had a significant positive effect on motivation (Z), there was no effect of financial compensation (X1) on employee performance (Y), leadership style (X2) has a positive and significant effect on employee performance $(\mathrm{Y})$, and finally working motivation $(\mathrm{Z})$ directly had a significant positive effect on employee performance $(\mathrm{Y})$. These results implied that financial compensation did not significantly affect employee motivation and performance. This was also stated by Purwanto et al. (2019) concerning the effect of work climate and motivation on the performance of vocational school teachers in Kendari City. The results showed that the compensation received by teachers had no effect on their performance. This result was predictable because the compensation did not reflect his performance. Thus, performance is not the basis for payment of teacher compensation in vocational schools in Muaro Jambi regency. Therefore, it was predicted that compensation did not affect teacher performance. The results will be different if the compensation payment system is determined based on work performance, it is almost certain that compensation will affect teacher performance.

Working climate affects teacher performance, the results of this study supported a study conducted by Purwanto, Ahiri and Momo (2019), which stated that the working climate should be quiet, comfortable, and conducive condition or atmosphere around the school able to support the learning process to improve student achievement. In the end, a conducive working climate was expected to have a positive impact on teacher performance in vocational schools in Muaro Jambi regency. The results of this study implied that the better the working climate in schools, the higher / better the teacher's performance would be. These results were consistent with previous study conducted by Hadi (2016).

Motivation affects teacherperformance, the results of this study were in accordance with the theory of Marthis and Jackson (2000), who stated that many factors affect the performance of a company, including working behavior, employees, motivation, support received, the presence of work they do, organizational culture and their relationship with the organization. Thus, it can be predicted that there was an increase in working motivation of teachers in vocational schools in Muaro Jambi regency and had an effect on improving teacher performance at a low level. This happens because motivation is the moderating variable of the study, where the amount is affected by supporting factors for the emergence of motivation itself, such as the desire for power, desire for affiliation, desire for achievement, and others. Thus, the amount of motivation is determined by the supporting factors which will have implications for positive performance behavior. These results were consistent with Ardiana's study (2017) regarding the effect of working motivation on the performance of accounting teachers in a vocational school in Ponorogo City which concluded that working motivation had a positive impact on accounting teacher performance with a contribution of $80.6 \%$.

Teacher professionalism competency affects teacher performance through motivation as a moderating/ indirect variable on teacher performance, efforts to make teachers have good professional competency will motivate teachers to work. It is believed that the professional competency of teachers will be able to motivate teacher work expected to have implications for reducing disciplinary action and improving performance so as to improve service quality and student learning achievement. A teacher who has high professional competency through positive stimulus or motivation from school leaders is predicted to be able to improve teacher work performance. Thus, teachers who have high professional competency and have strong 


\section{IRJE | Indonesian Research Journal in Education | | Vol. 5 | No. 1|June | Year 2021|}

motivation are predicted to perform higher. Likewise, teachers who have high competency but are not balanced with high work motivation are predicted to not affect their performance. Therefore, the results of this study were in line with Syamra's study (2016), who stated that several factors affect performance according to including salary system, job attractiveness, security and comfort in work, administration and management systems, physical and socio-cultural environment, career paths, and leadership. By understanding the factors that can affect teacher performance, these various problems can be found for solutions to not become an inhibiting factor in efforts to improve teacher performance.

Compensation affects teacher performance through motivation as a moderating or indirect variable on teacherperformance, motivation is a function that links compensation to employee performance and is indirectly determined by the overall compensation received by employees-paying rational and fair compensation as a school effort to stimulate teachers to strengthen their performance. It is believed that compensation will motivate teachers to strengthen morale, generate initiative at work, and reduce disciplinary action. Thus, an increase in the amount of compensation is predicted to strengthen teacher performance through strengthening work motivation. On the contrary, if the amount of compensation is not rational, it will weaken the work motivation of the teacher. The results of this study supported Handayani's study (2015) that the overall compensation received by workers had a positive effect on their behavior. However, this did not directly affect employee motivation to work in many ways. Additionally, this study was in line with research conducted by Soedarsono (2014), regarded the effect of compensation and motivation on the performance of employees. The results revealed that the magnitude of compensation and motivation variables on employee performance was $63.10 \%$, while other variables were $36.90 \%$. This meant that in affecting performance, the compensation and motivation variables played a role of $63.10 \%$.

Working climate affects teacher performance through motivation as a moderating or indirect variable on teacher performance, the social environment of the school such as relationships between individuals at school, motivation, teacher attitudes, responsibility, and individual participation in decision making, as well as mutual respect among school members. Therefore, the results of this study supported Hardjana's statement (2006). He emphasized that the elements of school climate were physical and social. The school's physical environment includes building conditions, classrooms, cleanliness, load and number of students in the class, light and temperature settings. Moreover, this study was in line with Sari's study (2019), which regarded compensation as affecting teacher motivation and performance due to path analysis's direct and indirect effects. This showed that compensation had a positive and significant effect on motivation directly. Motivation had a positive and significant effect on teacher performance, and compensation negatively affected teacher performance. The indirect relationship showed that compensation had a positive but weak effect on teacher performance through motivation as an intervening variable.

Teacher professional competency, compensation and working climate affected working motivation, teachers' high professional competency will motivate the teacher to work, improve service quality and student achievement, and reduce disciplinary action. The professional competency of teachers can be used as a factor that affects working motivation. Balanced compensation between the two types of compensation is believed to stimulate work motivation. The physical and socio-cultural environment in schools as the forming factors of working climate is 


\section{IRJE | Indonesian Research Journal in Education | | Vol. 5 | No. 1|June | Year 2021|}

predicted to affect teachers' working motivation. Therefore, the professional competency of teachers, compensation, and working climate are predicted to affect teacher working motivation. The result of this study was in line with the results of Susanto's study (2012) on the factors that affected the performance of vocational high school teachers. Therefore, there were positive and significant effects; (a) teacher Competency and principal leadership on working motivation in vocational school teachers in Hulu Sungai Selatan, South Kalimantan, either individually or together with a significance level of 0.038 ; 0.045 ; and 0.001 , (b) teacher Competency, principal leadership, and teacher working motivation on the performance of SMK teachers in Hulu Sungai Selatan Regency, either individually or collectively, and directly or indirectly had significance level of $0.036 ; 0.003 ; 0.036 ; 0.000 ;(0.038$ and 0.036$)$; (0.045 and 0.036).

Teacher professional competency, compensation, working climate, and working motivation affects teacher performance, Anoraga (2006) notes several factors that affect performance: salary system, job attractiveness, job security and comfort, management system, physical and social environment, career path, and leadership. By understanding the factors that can affect teacher performance, these problems can be found solutions so that they are no longer an obstacle to efforts to improve their performance. Shortly, the result of this study was in line with a study conducted by Hadi (2016) regarded the effect of organizational climate and teaching motivation on the performance of the vocational school, senior high school and Islamic high school teachers of Muhamadiyah in Kudus regency. More specifically, the effect of organizational climate variables (X1) and teaching motivation variables (X2) on the professional performance of teachers (Y) was 0.73 or $73.0 \%$. It can be inferred that there was a positive and significant effect between organizational climate and teaching motivation together on the performance of the vocational school. The organizational climate created by the principal can be formulated as a series of efforts to assist teachers in the form of professional services provided by the principal to improve the quality of teaching and learning processes and outcomes. Additionally, the organizational climate and teaching motivation also had a significant effect on teacher professional performance.

\section{Conclusions}

The performance of teachers in schools is affected by various internal and external factors. The professional competency of teachers is one of the determining factors for the success of learning. Efforts to improve teacher professional competency are expected to improve student achievement through enhanced motivation, methods, and working ethic. Teachers with high professional competency are expected to have better performance. Rational and fair compensation is believed to have an effect on teacher performance. Therefore, the compensation given to teachers should be able to motivate their performance. Besides that, it needs to be supported by a conducive working climate to strengthen motivation and improve teacher performance. In this case, working motivation is the spirit or drive in a person to do work in order to achieve goals that can have a positive effect in achieving better performance. Suppose the teachers have good professional competency and are provided with rational and reliable compensation in a conducive working climate. In that case, it will generate high motivation, which is expected to improve their performance. 


\section{IRJE | Indonesian Research Journal in Education | | Vol. 5 | No. 1|June | Year 2021|}

\section{Disclosure statement}

The author declares that there is no conflict of interest in relation to the publication of this article.

\section{Acknowledgments}

The author would like to extend his sincere appreciation and gratitude to the Indonesian Research Journal in Education (IRJE) for serving as an avenue for the publication of this article.

\section{References}

Anoraga. (2006). Psikologi kerja. Jakarta: Rineka Cipta.

Ardiana, T. E. (2017). Pengaruh motivasi kerja guru terhadap kinerja guru akuntansi SMK di Kota Madiun. Jurnal Akuntansi dan Pajak, 17(2).

Carrión, G. C., Henseler, J., Ringle, C. M., \& Roldán, J. L. (2016). Prediction-oriented modeling in business research by means of PLS path modeling: Introduction to a JBR special section. Journal of business research, 69(10), 4545-4551.

Chin, W. (1998). The partial least square approach to structural equation modelling. In G. A. Marcoulides (Ed.), Modern methods for business research (pp. 295-336). London, UK: Lawrence Erlbaum Associates

Creswell, J. W. (1999). Mixed-method research: Introduction and application. In Handbook of educational policy (pp. 455-472). Academic Press.

Creswell, J. W. (2011). Controversies in mixed methods research. The Sage handbook of qualitative research, 4, 269-284.

Fornell, C., \& Larcker, D. (1981). Evaluating structural equation models with unobservable variables and measurement error. Journal of Marketing Research, 18, 39-50. doi: $10.2307 / 3151312$.

Ghozali, I., \& Latan, H. (2015). Partial Least Squares, konsep, teknik dan aplikasi menggunakan program Smart PLS 3.0 untuk penelitian empiris. Semarang: Badan Penerbit UNDIP.

Hadi, I. S. (2016). Pengaruh iklim organisasi dan motivasi mengajar terhadap kinerja profesional guru SMA, SMK, MA Muhammadiyah di Kabupaten Kudus. QUALITY, 4(1), 199-216.

Hair, J. F, Anderson, R. E., Tatham, R. L., \& Black, W. C. (2010). Multivariat data analysis with reading, 4th eds. New Jersey: Prentice-Hall.

Hair, J. F., Sarstedt., M., Ringle, C. M., \& Gudergan, S. P. (2017). Advanced issues in partial least squares structural equation modeling. Sage Publications.

Hair, J. F., Hult, G. T. M., Ringle, C. M., Sarstedt, M., \& Thiele, K. O. (2017). Mirror, mirror on the wall: A comparative evaluation of composite-based structural equation modeling methods. Journal of the Academy of Marketing Science, 45(5), 616-632. 


\section{IRJE | Indonesian Research Journal in Education | | Vol. 5 | No. 1|June | Year 2021|}

Hair, J.F., Sarstedt, M., Ringle, C.M., Gudergan, S. P. (2017). Advanced issues in partial least squares structural equation modeling. SAGE Publications, Incorporated: Thousand Oaks, CA, USA,

Handayani, T. (2015). Pengaruh kompensasi terhadap kinerja guru. Jurnal Utilitas, 1(1), 24-34.

Hardiyana, A., Iskandar, S., \& Nurlaila, L. (2013). Pengaruh budaya organisasi dan kompensasi terhadap motivasi kerja serta implikasinya terhadap kinerja guru. Jurnal Ekonomi, Bisnis dan Entrepreneurship, 7(2), 64-73.

Hardjana, A. (2006). Iklim organisasi: Lingkungan kerja manusiawi. Jurnal Ilmu Komunikasi, 3(1), 99428.

Hasibuan. (2005). Manajemen sumber daya manusia. Jakarta. Bumi Aksara.

Hernández-Perlines, F., Moreno-García, J., \& Yañez-Araque, B. (2016). The mediating role of competitive strategy in international entrepreneurial orientation. Journal of Business Research, 69(11), 5383-5389.

Kadarisman. (2012). Manajemen pengembangan sumber daya manusia. Jakarta: Raja Garfindo Persada.

Kasman, H. (2018). Pengaruh kompetensi guru terhadap motivasi belajar siswa di SMA Negeri 10 Makassar. Doctoral dissertation, Universitas Islam Negeri Alauddin Makassar.

Kurniasih. (2018). Pengaruh kompetensi guru, iklim organisasi dan supervisi akademik kepala sekolah terhadap kinerja guru mata pelajaran pendidikan agama Islam Sekolah Dasar Negeri se-Kecamatan Sukoharjo tahun pelajaran 2017/2018. Tesis. Program Studi Manajemen Pendidikan Islam Pascasarjana IAIN Surakarta.

Soedarsono, D. K. (2014). Pengaruh Kompensasi dan Motivasi Terhadap Kinerja Pegawai SekolahMenengah Kejuruan Yayasan Bina Umat Al-Qomariah di Tasikmalaya. Available on: http:/ / ejumal.stiedharmaputra-smg.ac.id, accessed on May, 22, 2016.

Lubis, L. E. (2018). Efek kompensasi terhadap motivasi kerja guru pada Sekolah Widya Batam. Jurnal Dimensi Unrika, 7(3).

Madi, Kalimin, 2019. Pengarub Pemberian Tunjangan Sertifikasi Guru dan Motivasi Kerja Terbadap Kinerja Guru SMK Negeri 4 Kendari. Jurnal Bisnis Indonesia, Volume 10 Nomor 1 Tahun 2019, 45-56

Madi, R. A., \& Kalimin, L. O. (2019). Pengaruh pemberian tunjangan sertifikasi guru dan motivasi kerja terhadap kinerja guru SMK Negeri 4 Kendari. Jurnal Bisnis Indonesia, 10(1).

Maesaroh. (2018). Pengaruh motivasi kerja dan persepsi guru mengenai iklim kerja terhadap kinerja guru di MA Kota Semarang. Tesis, Program Studi manajemen Pendidikan Islam Pascasarjana IAIN Surakarta.

Mangkunegara. (2005). Sumber daya manusia perusabaan. Bandung : Remaja Rosdakarya.

Marsita \& Imaniyati. (2017). Kompensasi dan kepuasan kerja untuk meningkatkan kinerja guru. Jurnal Pendidikan Manajemen Perkantoran, 2(1), 44-56.

McClelland, D. C. (1985). Human motivation. Glenview, IL: Scott.

Mutakin. (2017). Pengaruh kompetensi, kompensasi, dan latar belakang terhadap kinerja guru. Jurnal Formatif 3(2), 145-156.

Ningsih. (2017). Pengaruh komitmen, kompetensi, dan lingkungan kerja terhadap kinerja guru di Kecamatan Pasangkayu Kabupaten Mamuju Utara. EJurnal Katalogis, 5(7), 181-190. 


\section{IRJE | Indonesian Research Journal in Education | | Vol. 5 | No. 1|June | Year 2021|}

Patarai, Mustari, \& Azis. (2018). Motivasi mengajar, kompetensi profesional dan tingkat pendidikan terhadap kinerja guru. Jurnal Mirai Management, 3(2).

Peraturan Menteri Pendidikan Nasional No 16 Tahun 2007. Standar Kualifikasi Akademik dan Kompetensi Guru. Jakarta: Depdiknas.

Peraturan Pemerintah No 19 Tahun 2005. Standar Nasional Pendidikan. Jakarta: Depdiknas.

Purwanto, Ahiri, \& Momo. (2019). Pengaruh iklim kerja dan motivasi terhadap kinerja guru SMKN di Kota Kendari. Jurnal Wahana Kajian Pendidikan IPS, 3(2).

Purwanto, P., Ahiri, J., \& Momo, A. H. (2019). Pengaruh iklim kerja dan motivasi kerja terhadap kinerja guru SMKN di Kota Kendari. Jurnal Wahana Kajian Pendidikan IPS, 3(2), 20-34.

Ratzmann, M., Gudergan, S. P., \& Bouncken, R. (2016). Capturing heterogeneity and PLS-SEM prediction ability: Alliance governance and innovation. Journal of Business Research, 69(10), 4593-4603.

Undang-Undang Nomor 20 Tahun 2003. Sistem pendidikan nasional.

Undang-Undang Nomor 14 Tahun 2005. Guru dan dosen.

Rivai V., Sagala E. J. (2011). Manajemen sumber daya manusia untuk perusabaan. Jakarta: Raja Grafindo Persada.

Riyadi, S. (2011). Pengaruh kompensasi finansial, gaya kepemimpinan, dan motivasi kerja terhadap kinerja karyawan pada perusahaan manufaktur di Jawa Timur. Jurnal manajemen dan kewirausahaan, 13(1), 40-45.

Robbins. (2006). Organizational behavior. New Jersey: Prentice Hall International.

Rowley C., \& Jackson, K. (2012). Management of human resources. Jakarta: PT. Raja Grafindo Perdana.

Sadili. (2006). Manajemen sumber daya manusia. Jakarta: CV. Pustaka Setia.

Sari, F. M. (2013). Pengaruh kompetensi dan lingkungan kerja terhadap kepuasan kerja dan kinerja guru di SD Negeri Kecamatan Gondang Mojokerto. Jurnal Ilmu Ekonomi dan Manajemen, 9, 140

Sari. (2018). Pengaruh lingkungan kerja dan motivasi kerja terhadap kinerja guru SMK Negeri 10 Muaro Jambi. EKLEKTIK: Jurnal Pendidikan Ekonomi dan Kewirausahaan, 1(1).

Sarstedt, M., Ringle, C.M., \& Hair, J. F. Partial least squares structural equation modeling. In Handbook of Market Research; Homburg, C., Klarmann, M., Vomberg, A., Eds.; Springer: Cham, Switzerland, 2017; pp. $1-40$

Sastrohadiwiryo. (2005). Manajemen tenaga kerja Indonesia pendekatan administrasi dan operasional. Jakarta: Bumi Aksara.

Shirokova, G., Osiyevskyy, O., \& Bogatyreva, K. (2016). Exploring the intention-behavior link in student entrepreneurship: Moderating effects of individual and environmental characteristics. European Management Journal, 34(4), 386-399.

Shook, C. L., \& Bratianu, C. (2010). Entrepreneurial intent in a transitional economy: an application of the theory of planned behavior to Romanian students. International Entrepreneurship and Management Journal, 6(3), 231-247.

Suharsaputra. (2010). Administrasi pendidikan. Bandung: Refika Aditama.

Susanto. (2012). Faktor-faktor yang mempengaruhi kinerja guru SMK Negeri 1 Daha Selatan Kabupaten Hulu Sungai Selatan Kalimantan Selatan. Jurnal Pendidikan, 2(2). 


\section{IRJE | Indonesian Research Journal in Education | | Vol. 5 | No. 1|June | Year 2021|}

Syamra, Y. (2016). Pengaruh kompensasi finansial dan motivasi kerja guru terhadap kinerja guru SMK Negeri Pariwisata di Kota Padang. Jurnal Economica: Research of Economic and Economic Education, 4(2), 258-268.

Uno, H. B. (2014). Teori motivasi dan pengukurannya: Analisis di bidang pendidikan. Jakarta: Bumi Aksara.

Vahim, M. R. D., Irdiana, S., \& Fauziah, A. (2019). Dampak Standar Kompetensi Manajerial Kepala Sekolah dan Iklim Sekolah terhadap Kinerja Guru SMK Negeri 1 Tempeh. Proceedings Progress Conference, 2(1), 460-466.

Wibowo. (2010). Manajemen kinerja. Jakarta: PT. Raja Grapindo Persada.

Widayati. (2019). Pengaruh kompensasi terhadap kinerja guru pada SDN Jatiwaringin X Bekasi. Jumal Widya Cipta, 3(1), 17-24.

Wuandari, P. (2018). Pengaruh kompetensi pedagogik, kompetensi sosial, kompetensi profesional terhadap kinerja guru di SDN Marunda 02 Pagi Jakarta Utara. Jurnal Pendidikan, 8(1), 13-26.

Yamin, M. (2010). Standarisasi kenrja guru. Jakarta: GP. Presa.

Yulia. (2017). Pengaruh motivasi kerja guru dan kompetensi pedagogik terhadap kinerja guru SMK Muhammadiyah 1 Prambanan Klaten. Skripsi, Prodi Pendidikan Administrasi Perkantoran, Jurusan Pendidikan Administrasi, Fakultas Ekonomi, Universitas Negeri Yogyakarta.

Zulkefi, Ridwan, \& Totanan. (2017). Pengaruh kompetensi profesional dan pedagogik terhadap kinerja guru akuntansi pada Madrasah Aliyah Negeri di kota Palu. E Jurnal Katalogis, 5(3), 67-77.

\section{Biographical note}

MUAZZA is an Associate Professor at Faculty of Teacher Training and Education, Universitas Jambi, Indonesia. 